\title{
What Books Taste Like
}

\author{
Bacon and the Borders of the Book
}

\author{
Jonathan P. Lamb
}

\begin{abstract}
This paper explores the language of book taste in early modern England to argue that a key shift occurred in Francis Bacon's famous aphorism about eating books: "Some bookes are to bee tasted, others to bee swallowed, and some few to bee chewed and digested: That is, some bookes are to be read only in partes; others to be read, but cursorily, and some few to be read wholly and with diligence and attention". Writers for the next century would quote and adapt this line, a process that would culminate in a shift from "taste" in the sense of sample to "taste" in the sense of discrimination and distinction.
\end{abstract}

To ODAY, I WOULD LIKE TO ADD A RED-LETTER DATE TO THE HISTORY of the book: 1597. The 1590s already represent a crucial turning point in what some call print culture. In this decade, the Marprelate controversy, the 1599 Bishops' Ban, the explosion of prose romances and sermon collections, and other key events and changes in the book trade confirmed the place of printed books at the center of English culture - particularly in London. As Georgia Brown has so energetically demonstrated, the 1590s "were characterized" (yes) "by the expansion of literary activity" but also a revolution in which "writers and readers started to express a changing sense of the forms and functions of literature" (2004, 4). Extending Brown's analysis, Samuel Fallon's recent book Paper Monsters explores the way in which literary personae of the 1590s function as "products of [. . . ] the reflexive consciousness of a hybrid media culture" (hybrid in the sense of manuscript and print) $(2019,16)$. The 1590 s were clearly a key moment in the relationship between the print medium and imaginative literature.

But I aspire to identify a much more specific date, not because I think these accounts are wrong but because they point us to an even bigger history of mediation. At stake in scholarship on the 1590s is the question of how a culture becomes bookish - that is, how a culture becomes not just literary in the familiar modern sense but in the premodern sense, "of or 
pertaining to books". If there was a print culture before 1700, then it existed in the sense that books signified. So rather than a print culture, which has an uneasy metonymical relationship with the press, we might speak of a bookish culture, in which books acquired a set of durable associations. And that's why 1597 is such an important date: in that year, Francis Bacon's Essayes were first published, featuring this crispy nugget of Baconian brevity: "Some bookes are to bee tasted, others to bee swallowed, and some few to bee chewed and digested: That is, some bookes are to be read only in partes; others to be read, but cursorily, and some few to be read wholly and with diligence and attention". ${ }^{2}$ I want to explore the premodern story of books and their relationship with taste. My main claim is that Bacon's statement forms a kind of hinge in the story, in which books acquire a new set of signifying capacities and the story of mediation takes a turn for the modern.

Bacon's axiom doesn't make gastrointestinal sense. The relationship between tasting a book metaphorically and reading seems relatively clear. To taste a book is to take in parts of it, in Bacon's words. It's not entirely clear, however, what mode of reading Bacon has in mind here. If he's thinking about instrumental reading, such as consulting a dictionary or perhaps the practice of commonplacing, then the taste readers get is the point of the book. But he doesn't say that, and the fact that this is initially a statement about books, as distinct from reading, suggests a value-laden judgment. Some books, he implies but does not state, are worth just a sample. But the metaphor gets still more complicated as it elaborates. The difference between swallowing a book and chewing and digesting a book is a bit fuzzier. Surely Bacon knew - unless I'm missing something in the anatomical discourse that suggests otherwise - that to swallow something is part of digesting it. Swallowing and digesting don't seem distinct enough to measure the difference between cursory and diligent reading — unless, of course, we change our focus from the eaten to the eater. The fuzziness of the differences notwithstanding, readers know the difference Bacon is trying to describe. It's one thing to swallow a book, but to chew on it, to read it with attention - now that's digestion. Incidentally, this is an exemplary case of Stanley Fish's (1972) reading of Bacon's Essays as self-consuming artifacts: to fully understand this metaphor, we have to digest it ourselves.

1. See the OED entry for "bookish": "Of or pertaining to books; entered in books; according to books; bookish" (III, 17).

2. For ease of reference, citations of early modern titles refer to their STC and Wing catalog numbers in the English Short Title Catalogue. STC 1137, sig. B1v. 
In a flash, what begins as a statement about books, the grammatical subject of the sentence, becomes a statement about readers, the agents who effect the distinction between tasting, swallowing, and chewing.

The metaphor of tasting books didn't come from nowhere. One might begin with the early hermeneutic notion of the integumentum or covering of a text, which often conceptualized reading as the removal of a shell or husk to eat the nut or juice beneath. The metaphor evolved with the sixteenth century print market. In my research, I have uncovered hundreds of writers comparing reading to tasting and eating. The 1519 translation of Raymond of Capua's Life of Saint Catherine of Siena criticizes wrongful interpretations of the Bible: "they vnderstonde rather holy wrytte after the letter or after theyr owne felynge than after the very vnderstondynge \& so by tastynge onely of the lettre they make many bokes but they taste not the pythe [.. .]". The tasting of letters is distinct from tasting the pith of the Bible - an assertion that seems less like a form/content claim than one about mediation. Letters, instead of conveying the "very" or true "understanding", stimulate the production of misreading — and more books. Merely tasting letters leads to failed comprehension. Thomas More uses a similar metaphor to describe successful comprehension. More declares that when the person who has argued against him can "proue his worde [against More] wysely spoken", then that man should "kepe one copye therof wyth hym selfe for lesynge, \& sende an other to me and than that copye that I receyue, I wyll be bounden to eate it though the booke be bounden in bordes". ${ }^{4}$ Here, eating the book means not just grasping the writer's point (in the sense of comprehension) but acknowledging the successful proof of that point. More's little joke on the word "bounden" suggests his skepticism that the writer can prove his objection. It also highlights the deliberate bookishness of this particular moment, as we imagine the great More shrugging his shoulders with resignation as he begins to eat a bound book.

This notion of tasting or eating books was fairly common throughout the sixteenth and seventeenth centuries, with writers using the metaphor as a model for understanding. Pierre Viret complains about people who cannot "applye themselues to reade those good bookes, and can take no taste of them, bicause that their mouthe is not fitte for such meate, and that they are to precious for them". 5 These readers cannot apprehend good books. Somewhat differently, Foxe's Actes and Monuments notes that the

3. STC 4815, sig. miiiiv.

4. STC 18078, sig. F2v.

5. STC 24776, sig. B7v. 
people of Bohemia came "to the knowledge of Wickliffes bookes here in England", and therefore "began first to taste and sauor Christes gospell". ${ }^{6}$ By way of books, the Bohemians taste something else. (I ought to mention, parenthetically, that later writers would grab this particular phrase "taste and savor" - in reference to evangelism. ${ }^{7}$ ) In a book on the history of the Netherlands, Jean Francois Le Petit's translator refers readers to "the books themselues", where they "shall haue better tast and information". ${ }^{8}$ Shakespeare's sonnet 77 assures us that "of this booke, this learning maist thou taste". ${ }^{9}$ You get the idea: taste and eating easily fill at least one of the variables in descriptions of understanding.

We might benefit from a taxonomy of this language. Most references to eating books imply comprehension, while references to tasting books usually imply sampling. The nearly archetypal instance of the first category is Revelation 10:9, here in the Coverdale translation: "Take the boke, and eate it vp, and it shall make thy belly to become bytter, but in thy mouth it shalbe swete as hony: And I toke the boke of the angels hande, and I dyd eate it vp, and it was swete in my mouth as hony". 10 This verse served all sorts of writers as a metaphorical prompt. The preacher Henry Smith, for instance, wrote that

As the Angel taught Iohn to reade the booke when hee bad him eate it: So we must put on Christ, as if wee did eate him, not as the Papists doe in their Masse, but as the meate is turned into the substance of the body, and goeth through euery part of man: So Christ \& his worde should goe from part to part, from eare to heart, from heart to mouth, from mouth to hand, till wee be of one nature with them, that they bee the very substance of our thoughts \& speeches, and actions, as the meate is of our bodies. This is to eate Christ and his word, or els wee doe not eate them, but chew them, and when our tast is satisfied, spue them out againe. ${ }^{11}$

Smith's appeal to eating-as-comprehension leads him to taste-as-sample. Likewise, Samuel Ward complains about those who "reade the Bible by fits vpon rainy dayes, not eating the booke with Iohn, but tasting onely
6. STC 11225, fol. 588 .
7. See, for instance, STC 23592, sig. Ee4r.
8. STC 12374 , fol. 1408.
9. STC 22353, sig. E4v-Fr.
10. STC 2816, sig. Cciir.
11. STC 22713, sig. C3r-C4v. 
with the tippe of the tongue". These rainy-day readers, he says, "meditate by snatches, neuer chewing the cud and digesting their meat, they may happely get a smackering for discourse and table-talke; but not enough to keepe soule \& life together, much lesse for strength and vigour". ${ }^{12}$ Ward's reference to the Revelation verse slingshots him into the second category of taste-as-sample.

And this second category was everywhere, as writers used the metaphor of taste to stand in for the idea of sampling a book. Martin Luther, in translation, reports that "Surely a very small tast of this booke [Ecclesiastes] was to me a great pleasure". ${ }^{13}$ John Bale, in his Pageant of Popes, offers "in this booke a little taste of theyr [that is, the popes'] vnsauorye liues". ${ }^{14}$ Thomas Cartwright writes to his opponent that, "not to waste paper in rehersall of all: I will onely giue a tast of your later book". ${ }^{15}$ The preface to John Calvin's enormous book of sermons on Deuteronomy offers "to giue the readers some tast of the whole booke of the said sermo[n]s". ${ }^{16}$ In these and the dozens and dozens of other cases of this language from the period, the metaphor offers a thorny theory of mediation. In most instances, a taste of a book (that is, a sample) cannot and must not stand in for knowledge of the whole book. These examples here tend to work upon the assumption that a taste does not confer or convey sufficient knowledge of the book to the extent that a taste can be equivalent to the whole thing. A taste of Calvin's sermons is supposed to offer us some idea of what those sermons consist of, but the taste cannot and is not supposed to replace the actual reading of the sermons. If a taste, in this line of thinking, can mediate, it does so by approximation, which is after all the whole point of the metaphor. Peter Vermigli (or Peter Martyr) helpfully traces out this theory of mediation by criticizing partial reading:

Mans wisedome as it hath bin accustomed, began to loath and contemne the holy scriptures, as though the same were now wearie of Manna, and of the bread giuen from heauen, and it iudged the holy scripture to be so vile and simple, as though it could straightwaie attaine to the whole vnderstanding thereof euen with one twinke of eye, and with one breath. It supposed it to be ynough to reade ouer the same once, and by a taste of

12. STC 25039, sig. E5r-v.

13. STC 16979, sig. A5v.

14. STC 1304, sig. *a8v.

15. STC 4714 , sig. $4 \mathrm{r}$.

16. STC 4442, [Pilcrow]3v. 
one or two Bookes it iudged of the whole woorthinesse thereof, it laide it aside and determined to séeke wisedome elsewhere also. ${ }^{17}$

Vermigli critiques those who think, wrongly in his mind, that a taste of the Bible can adequately replace knowledge of the whole. This is not, of course, an either-or situation, in which a taste either replaces or does not replace the whole book. Rather, the notion of mediation in view in these many examples is distinctly premodern, modelled as an intimate and embodied interaction that, when imagined as a taste, does not satisfy.

And this brings us back to Bacon, who makes a subtle but important reconfiguration of the metaphor. Whereas in most cases (like all the ones above), the emphasis of the metaphor falls on the insufficiency of a taste to mediate, Bacon's line suggests that it is sufficient. Some books are just to be tasted, and a taste is, specifically, all you need. In the calculus of Bacon's metaphor a reader doesn't need to ingest fully the whole book, but just read it "in parts", and those parts stand in for and can effectively replace the whole. The emphasis, as I argued earlier, falls rather on the reader's capacity to distinguish between books worth tasting and books worth swallowing or digesting.

Bacon's reconfiguration of an extremely common metaphor is special, though not unique. Other writers referred to tasting books as a sufficient replacement for the whole. What makes Bacon's version special is, first, that he crosses the idea of tasting as sample with the idea of eating as comprehension, and, second, that dozens of writers repeated his line and used it as a prompt, just as writers used Revelation 10:9. By rerouting the notion of taste from a quality of books to a faculty of readers, even as his line suggests that a taste is all you need, Bacon opens the door for the modern notion of taste as aesthetic discrimination. The OED calls this kind of taste "a sense of what is appropriate, harmonious, or beautiful", specifically "the faculty of perceiving and enjoying what is excellent in art, literature, and the like". ${ }^{18}$ OED dates this notion of taste to 1671, in Milton's Paradise Regained, which refers to "Sion's songs, to all true tasts excelling, Where God is prais'd aright". The OED then cites William Congreve's 1694 Double-dealer — "No, no hang him, he has no tast" — followed by Joseph Addison in the Spectator: "1 Rules how we may acquire that fine Taste of Writing, which is so much talked of among the Polite World". In the space of three quotations, we arrive at the modern notion of taste as an

17. STC 24669, sig. Cc5r.

18. See the OED entry for "taste", 8.a. 
assertion of cultural distinction and superiority, which Pierre Bourdieu and plenty of others have described. ${ }^{19}$ The key assumptions in the development of this notion of taste are that the person in possession of it can discern the value of things, and that this discernment is implicitly marked by disembodiment. The elite, tasteful reader has everything but a body.

To put too fine a point on it, this is the very assumption that Bacon formulates in his statement about tasting, swallowing, and eating books. Underwriting the modern notion of taste - this idea of aesthetic judgment that informs the best and worst of modernity - is a twist in the theory of mediation in which a taste of a book goes from being not enough to being more than enough. What was, for most writers, a mark of deficiency becomes, in Bacon's aphorism, a ranked sufficiency (we taste James Patterson, swallow the New Yorker, and chew and digest Toni Morrison). This move seems to invert Jacques Derrida's notion of the trace, which Juliet Fleming glosses as the term used "to suggest that what a signifier marks is not only 'not there' but, more importantly, 'not that'; the trace is not the remainder of something gone but the mark of what was never fully there" (2016, 7). Bacon's line works in the opposite direction: whereas for many writers, perhaps channeling Derrida avant la lettre, a taste marks insufficient mediation, for Bacon a taste can and does constitute presence. Indeed, that he then elaborates the metaphor in terms of swallowing, chewing, and digesting as more intensive forms of making books present to oneself suggests precisely this vector of thinking. If Derrida's notion of the trace aims to dismantle a modern notion of mediation rooted in a metaphysics of presence, then in Bacon's aphorism we see the very formulation of that modern idea - formulated, it's worth repeating, in language concerning books. For Bacon, a taste of a book is a trace that can make that book present to the taster.

As I mentioned, later writers adapted Bacon's line with great relish. Most use his threefold division as a way of distinguishing which books are worth tasting, swallowing, or chewing and digesting. Richard Braithwaite, for instance, explains that books worth tasting include "Stories of modest accomplement, superficiall flourishes" and so on, whereas the "Amorous, and fruitlesse labours of braine-sicke Authors" are for swallowing, and "discourse tending both to instruction and delight" is worth chewing and digesting. ${ }^{20}$ Other writers pick up on the implicit theory of mediation. Edward Leigh, for instance, in a 1646 preface to the reader, writes that

19. See Bourdieu 1984; see also Guillory 1993.

20. Wing B4265, sig. Ss2r-v. 
"The number of bookes is without number, the Presses are daily oppressed with them. Yet (though the world abound with unprofitable, nay pernicious Pamphlets) there are many excellent subjects which are either not handled, or not sufficiently. There is a great variety in mens fancies as well as in their faces; and bookes (the fruit of mens brains) are as various as men themselves. Some books are to be tasted onely, some chewed, and some swallowed". ${ }^{21}$ The aphorism punctuates Leigh's attempt to articulate what to do with all the books coming off the press. This is not a Lockean theory of communication, by which ideas are transmitted from one brain to another by way of the medium of words. But it's close. Leigh presents the variety of books as a reflection of the variety of human consciousness, with the faint suggestion (by way of the fruit metaphor) that access to and distinction among books entails access to and distinction among people. For Leigh, as for Bacon, as for Bourdieu, to have a taste is not merely to sample but to judge what matters.

Let me return in conclusion to the terms with which I began: the proposal that the language of books and taste does not show us an emerging print culture but an established and continually unfolding bookish one. The difference between these two cultural models cannot be overstated. In one, books both ground and produce cultural change; I don't need to rehearse for this audience the scholarship critiquing the idea of print culture. In the other, books have signifying functions related to but distinct from their status as text carriers - that is, as media. Francis Bacon's aphorism, we might say, gives us a taste of the bookish culture in early modern England.

University of Kansas

\section{Works Cited}

Bourdieu, Pierre. 1984. Distinction: A Social Critique of the Judgement of Taste. Cambridge: Harvard University Press.

Brown, Georgia. 2004. Redefining Elizabethan Literature. Cambridge and New York: Cambridge University Press.

English Short Title Catalogue. N.d. London: British Library.

Fallon, Samuel. 2019. Paper Monsters: Persona and Literary Culture in Elizabethan England. (Material Texts). Philadelphia: University of Pennsylvania Press.

Fish, Stanley. 1972. Self-Consuming Artifacts; the Experience of Seventeenth-Century Literature. Berkeley: University of California Press.

21. Wing L1011, sig. ***3r. 
Fleming, Juliet. 2016. Cultural Graphology: Writing after Derrida. Chicago: The University of Chicago Press.

Guillory, John. 1993. Cultural Capital: The Problem of Literary Canon Formation. Chicago: University of Chicago Press. 